\title{
Kritik Sosial dalam Stand Up Comedy (Analisis Semiotika Show "Pragiwaksono World Tour")
}

\author{
Reynord Leonardo, Ahmad Junaidi \\ Reynord88@gmail.com,ahmadd@fikom.untar.ac.id \\ Fakultas Ilmu Komunikasi Universitas Tarumanagara
}

\begin{abstract}
This study discusses the stand up comedy that is popular among the people. Stand up comedy itself is a singular comedic art whose contents from ordinary jokes contain social criticism. Pandji Pragiwaksono is one example of a comic where he likes to bring stand up comedy material containing social criticism where there are some social problems that we are experiencing in the form of comedy. The theory used by researchers is the theory of mass communication, mass media, social criticism, stand up comedy. This study uses a qualitative approach with the semiotic analysis technique method Ferdinand De Saussure which divides the selected sign into two namely signifier and signified. In this study it was found that the show stand up comedy made by Pandji Pragiwaksono namely Pragiwaksono World Tour slipped a number of social criticisms in which social criticisms were presented including criticism of children's names, criticism of children 's Youtubers, critics of PSSI chairmen, critics of the profession of people, criticisms of humanity, criticism about fans, criticism about animals, and criticism of the attitude of Indonesian citizens. The result is stand up comedy is not just a tool to entertain the public but can also slip social criticism in the form of comedy criticism delivered by Pandji made with satire and comedy so that the message received can be captured easily by his listeners.
\end{abstract}

Keywords: mass communication, stand up comedy, social criticism, semiotics, ferdinand de saussure.

\begin{abstract}
Abstrak
Penelitian ini membahas tentang stand up comedy yang sedang populer dikalangan masyarakat. Stand up comedy sendiri merupakan seni melawak secara tunggal di mana isi dari lawakan berupa kritik sosial. Pandji Pragiwaksono menjadi salah satu contoh komika di Indonesia yang membawakan materi stand up comedy berisi kritik sosial terhadap beberapa masalah sosial. Teori dan konsep yang digunakan peneliti adalah komunikasi massa, media massa, kritik sosial, stand up comedy. Penelitian ini menggunakan pendekatan kualitatif dengan metode teknik analisis semiotika Ferdinand De Saussure yang membagi tanda menjadi dua yaitu signifier dan signified. Penelitian ini menemukan bahwa pertunjukan stand up comedy Pandji Pragiwaksono yaitu Pragiwaksono World Tour menyelipkan beberapa kritik sosial antara lain kritik nama anak, kritik youtuber anak-anak, kritik ketua PSSI, kritik tentang profesi orang, kritik kemanusiaan, kritik tentang fans, kritik tentang satwa, dan kritik sikap warga Indonesia. Kesimpulan dari penelitian ini yaitu stand up comedy bukan menjadi alat untuk menghibur masyarakat namun juga menyelipkan kritik sosial dalam bentuk komedi kritik yang dibuat dengan satir dan komedi sehingga pesan yang diterima dapat ditangkap dengan mudah oleh pendengarnya.
\end{abstract}

Kata Kunci: komunikasi massa, stand up comedy, kritik sosial, semiotika, ferdinand de saussure. 


\section{Pendahuluan}

Komunikasi merupakan suatu hal yang dilakukan oleh manusia untuk berinteraksi dengan sesama manusia. Manusia mengembangkan komunikasi dan menyampaikan pesan-pesan baik untuk berinteraksi dan menyampaikan gagasan. Terdapat berbagai cara untuk bisa melakukan komunikasi antara lain secara langsung dan juga dengan menggunakan berbagai media tertentu.

Salah satu media yang dapat dijadikan sebagai wadah untuk menyampaikan gagasan adalah stand up comedy. Stand up comedy merupakan suatu seni berkomedi yang dilakukan secara individu. Isi dari stand up comedy biasanya merupakan keresahan yang dialami oleh komika sehingga pesan yang dibawakan cenderung mengkritik. Stand up comedy dijadikan komika sebagai wadah untuk menyampaikan gagasan atau aspirasi mereka akan masalah atau suatu hal yang aneh di masyarakat yang sedang terjadi.

Stand up comedy di Indonesia mulai populer pada saat mulai muncul di televisi nasional tahun 2011. Materi stand up comedy yang dibuat langsung oleh komika biasanya membawa isu - isu yang sedang terjadi di masyarakat. Hal ini membuat penonton yang menyaksikan stand up comedy merasa tersinggung dengan materi yang dibawakan oleh komika tersebut. Hal ini karena penonton salah menangkap maksud dari pesan atau lawakan yang ingin disampaikan oleh komika. Banyak komika yang terkena kasus dan juga dihujat oleh masyarakat karena materi yang mereka bawakan.

Miskomunikasi dapat menjadi alasan penonton tidak menangkap pesan yang ingin disampaikan oleh komika. Miskomunikasi juga sering terjadi pada saat ingin berkomunikasi dengan orang lain. Hal ini dapat menjadi masalah di kehidupan sosial manusia, karena kita jadi tidak bisa mengambil pesan inti yang ingin disampaikan oleh seseorang.

Salah satu komika terkenal di Indonesia antara lain adalah Pandji Pragiwaksono. Pandji Pragiwaksono sering membawakan materi stand up comedy yang isinya mengkritik kehidupan sosial di Indonesia. Pandji Pragiwaksono sering membuat tur stand up comedy. Materi yang dibawakan mengangkat isu-isu sosial di dalam salah satu show yang banyak mengkritik kehidupan sosial pada masyarakat Indonesia adalah Pragiwaksono World Tour. Pandji Pragiwaksono juga pernah berhadapan dengan kasus hukum akibat materi yang dibawakan membahas tentang satwa. Hal ini memperlihatkan bahwa masih banyak orang yang tidak bisa mengambil pesan yang ingin disampaikan oleh komika.

Dari latar belakang tersebut, dapat dilihat bahwa ketika berkomunikasi, menyampaikan kritik, dan juga gagasan, tidak lepas dari miskomunikasi. Peneliti ingin membahas tentang bagaimana penyampaian kritik sosial yang terdapat pada stand up comedy Pandji Pragiwaksono "Pragiwaksono World Tour" Tujuan dari penelitian ini ingin membahas tentang apakah pesan kritik sosial yang disampaikan oleh komika dimengerti oleh masyarakat.

Menurut Maletzke (dalam Romli, 2016), komunikasi yang disampaikan secara terbuka pada suatu media yang dapat menyebarkan pesan yang disampaikan secara tidak langsung dan hanya satu arah dan penerima pesan berada pada berbagai tempat itu merupakan bentuk komunikasi massa. Bittner (dalam Romli, 2016) juga menjelaskan kalau komunikasi massa adalah bentuk komunikasi yang menggunakan media sebagai perantara yang pesannya di sebarkan ke banyak orang. 
Media massa adalah sebuah media yang dapat menyampaikan pesan kebanyak orang secara luas. Cangara (2010), menjelaskan bahwa media massa adalah alat yang bisa dipakai untuk menyampaikan pesan dengan memakai alat yang digunakan untuk komunikasi yang bertujuan untuk dapat memberikan pesan kepada khalayak secara luas. Menurut Cangara (2010), ada berbagai jenis media yaitu media cetak, media elektronik dan media internet. Pada saat ini media internet menjadi media yang paling banyak diakses.

Semiotika merupakan kata yang ada pada Yunani yang berarti tanda. Ferdinand De Saussure menjelaskan (dalam Sobur, 2017), semiotika merupakan suatu ilmu yang mempelajari tentang peran tanda. Hal terpenting dalam semiotika adalah bagaimana kita dapat memahami suatu tanda. Sementara, menurut Amalia (2006), kritik sosial merupakan suatu penyampaian tanggapan yang dilontarkan kepada suatu peristiwa yang sedang terjadi dilingkungan masyarakat dianggap tidak sesuai dengan yang seharusnya.

\section{Metode Penelitian}

Penelitian ini menggunakan pendekatan kualitatif. Menurut Moleong (2017), pendekatan kualitatif merupakan bentuk penelitian yang bertujuan untuk dapat memahami suatu hal tentang apa yang sedang dialami oleh subjek penelitian seperti perilaku, persepsi, motivasi, tindakan dan masih banyak lagi hal ini dilakukan dengan menggunakan kata-kata atau bahasa untuk menjelaskan suatu konteks.

Peneliti memilih pendekatan kualitatif karena dapat menjelaskan fenomena stand up comedy sebagai media kritik di Pragiwaksono World Tour. Metode penelitian yang digunakan peneliti adalah metode semiotika Ferdinand De Saussure yang berfokus pada tanda. Dalam metode semiotika Ferdinand De Saussure terdapat bentuk pemahaman tanda-tanda dengan bentuk signifer yaitu coretan atau suatu bunyi yang memiliki suatu makna tentang apa yang dibacakan, dituliskan atau apa yang dapat dikatakan. Kemudian bentuk Signifed yang merupakan suatu gambaran suatu konsep atau buah pikiran dari suatu aspek, mental dan bahasa.

Teknik pengumpulan data adalah wawancara. Peneliti mewawancarai narasumber yang ahli terkait stand up comedy. Narasumber yang dipilih adalah Coki Pardede, yang berprofesi sebagai komika. Narasumber ikut serta dalam Pragiwaksono World Tour. Coki Pardede dipilih sebagai narasumber karena memiliki kemampuan untuk menjelaskan tentang stand up comedy dan Pragiwaksono World Tour.

Objek penelitian ini adalah materi stand up comedy pada Pragiwaksono World Tour yang mengandung unsur representasi dari kritik sosial. Hal ini terlihat dari gambar Pandji Pragiwaksono yang sedang membawakan materi stand up comedy yang dianggap sedang mengkritik kehidupan sosial dan akan dijelaskan menggunakan teknik semiotika Ferdinand De Saussure.

Teknik pengumpulan data yang digunakan adalah data primer yaitu dokumentasi. Menurut Guba dan Lincoln (dalam Moleong, 2017), dokumentasi merupakan bahan yang tertulis maupun film yang tidak dipersiapkan karena terdapatnya permintaan penyidik. Data sekunder yang digunakan adalah wawancara yang tidak terstruktur. Herdiansyah (2010) mengatakan bahwa wawancara adalah suatu percakapan yang dilakukan oleh dua orang pihak yaitu pewawancara dan narasumber. 
Wawancara yang digunakan hanya berupa garis besar suatu permasalahan yang akan ditanyakan kepada ahli untuk keperluan menjawab pertanyaan penelitian. Peneliti menggunakan studi pustaka yakni mengumpulkan bahan yang diperlukan dari stand up comedy Pragiwaksono World Tour, buku yang relevan dan dapat mendukung penelitian. Data yang sudah disaring dan didapatkan diolah dengan menggunakan penafsiran analisis semiotika Ferdinand De Saussure.

Teknik keabsahan data dilakukan dengan empat teknik pemeriksaan yaitu derajat kepercayaan, keteralihan, kebergantungan, dan kepastian. Peneliti menggunakan derajat kepercayaan untuk mencari dan menemukan data sehingga tingkat kepercayaan bisa didapatkan oleh peneliti data yang diberikan juga bisa dijamin kredibilitas hasil yang ditemui oleh peneliti dengan pembuktian dari peneliti.

\section{Hasil Temuan dan Pembahasan}

Pragiwaksono World Tour merupakan show special stand up comedy yang dibuat oleh Pandji Pragiwaksono. Pada tour stand up comedy ini Pandji Pragiwaksono materi yang dibawakan olehnya tidak seberat biasanya. Materi yang dibawakan Pandji Pragiwaksono pada Pragiwaksono World Tour lebih personal dimana ia terinspirasi dari komika di luar negeri yaitu Hasan Minhaj. Namun, Pandji Pragiwaksono juga tidak meninggalkan ciri khasnya dimana ia suka mengangkat isuisu yang sedang terjadi di masyarakat.

Isi dari show stand up comedy Pragiwaksono World Tour menceritakan tentang kehidupan Pandji Pragiwaksono dari lahir hingga sekarang dan juga membawakan materi lain dimana Pandji Pragiwaksono membawakan isu-isu sosial. Peneliti menganggap ini merupakan sebagai kritik sosial yang ingin disampaikan Pandji Pragiwaksono kepada penonton.

Setelah peneliti melakukan penelitian dengan menggunakan metode analisis semiotika Ferdinand De Saussure, peneliti mengambil 9 materi stand up comedy yang peneliti anggap merupakan materi yang bersifat kritik sosial yang disampaikan oleh Pandji Pragiwaksono. Materi tersebut mengkritik tentang nama anak, kritik YouTube anak-anak, kritik ketua PSSI, kritik tentang profesi seseorang, kritik tentang kemanusiaan, kritik tentang fans, kritik tentang satwa, kritik sikap warga Indonesia.

Hasil dari wawancara dengan ahli yaitu Coki Pardede didapatkan bahwa Pandji Pragiwaksono merupakan komika yang berani menyampaikan opini yang ia miliki yang disampaikan dalam bentuk komedi. Opini yang disampaikan oleh Pandji Pragiwaksono merupakan masalah yang ada dan sedang dialami di Indonesia. Pembawaan kritik sosial yang disampaikan oleh Pandji Pragiwaksono dibawakan dalam bentuk komedi sangat mendukung karena dengan komedi orang lebih mau mendengarkan tanpa merasa digurui dan opini yang disampaikan bisa sampai pada pendengarnya. Hal lain yang didapatkan adalah stand up comedy bisa dijadikan sebagai media kritik. Hal ini didasari dari materi yang dibuat oleh komika merupakan keresahan yang mereka rasakan tentang apakah ada yang salah atau aneh pada masyarakat dan pemerintah, serta terkait gaya hidup.

Stand up comedy merupakan komedi yang dibawakan secara satir namun stand up comedy tidak harus dituntut untuk selalu membawakan isu-isu sosial. Komedi yang dibawakan lucu tanpa harus mengkritik suatu hal. Wawancara dengan Coki Pardede juga mendapatkan jawaban kenapa orang bisa tersinggung terhadap materi stand up comedy. Setiap materi stand up comedy yang dibawakan akan 
menimbulkan ketersinggungan. Pada dasarnya materi stand up comedy yang dibuat merupakan hasil dari opini komika tersebut di mana opini pasti ada yang setuju dan tidak setuju. Walaupun materi yang dibuat sudah diupayakan untuk sedikit mungkin menyinggung orang, namun tetap akan ada yang tersinggung. Coki Pardede disini menyampaikan orang akan pasti tersinggung dengan materi stand up comedy apapun karena setiap orang memiliki hal yang menurut mereka penting, dan hal yang penting tersebut berbeda satu sama lain. Hal ini semakin diperparah dengan adanya media sosial di mana semua orang yang tersinggung akan hal yang sama dapat bertemu dan saling memperkuat ketersinggungan mereka akan suatu hal sehingga tidak akan ada stand up comedy atau komedi yang aman. Artinya, tidak ada stand up comedy di mana semua orang dapat menerima dan tidak ada yang tersinggung.

Stand up comedy Pandji Pragiwaksono pada Pragiwaksono World Tour dapat dijadikan sebagai media kritik sosial. Pragiwaksono World Tour memberikan gambaran bahwa masih banyak hal yang harus diubah pada masyarakat Indonesia. Komika juga menjadi pekerjaan yang beresiko karena bisa membuat orang tersinggung bila materi tersebut dibagikan di media sosial karena semua orang dapat mengakses. Pada saat ini, bila ingin mencari materi stand up comedy yang memiliki nilai-nilai yang ingin komika sampaikan, hal tersebut akan lebih banyak pada acara show dan juga off air. Tujuannya untuk menyeleksi orang-orang yang benar-benar ingin menonton.

\section{Kesimpulan}

Stand up comedy Pandji Pragiwaksono pada Pragiwaksono World Tour didapatkan tanda-tanda tentang materi stand up comedy yang mengandung kritik sosial yang disampaikan secara satir. Kritik-kritik tersebut adalah kritik dalam membuat nama anak, kritik tentang YouTube anak-anak, kritik ketua PSSI, kritik tentang profesi seseorang, kritik tentang kemanusiaan, kritik tentang fans, kritik tentang satwa, kritik sikap warga Indonesia yang disampaikan dalam bentuk komedi.

Peneliti menemukan materi kritik sosial tersebut pada adegan show di Pragiwaksono World Tour. Media sosial berperan atas kasus yang dialami oleh Pandji Pragiwaksono dimana orang tersinggung dengan materi stand up comedy yang ia bawakan pada Pragiwaksono World Tour. Tujuan awal Pandji Pragiwaksono melakukan hal tersebut untuk mempromosikan show. Hal ini dapat terjadi karena materi stand up comedy berbentuk opini dari komika tersebut sehingga tidak semua orang dapat menyetujui materi tersebut.

\section{Ucapan Terima Kasih}

Peneliti mengucapkan terima kasih kepada seluruh pihak yang membantu peneliti dalam melaksanakan penelitian ini, bapak Coki Pardede yang bersedia menjadi narasumber ahli dalam penelitian ini serta kepada seluruh keluarga dan teman peneliti yang mendukung dalam penelitian ini.

\section{Daftar Pustaka}

Andriansyah, Yani. (2018, Juli 28). '5 Fakta Tur Keliling Dunia Stand Up Comedy Pandji Pragiwaksono'. April, 24 2020. Brilio database. 
Vol. 4, No. 2, Oktober 2020, Hal $185-190$

https://www.brilio.net/sosok/5-fakta-tur-keliling-dunia-stand-up-comedypandji pragiwaksono--180728o.html

Cangara Hafied. (2010). Pengantar Ilmu Komunikasi. Jakarta : PT. Raja Grafindo Persada.

Juditha, C. (2018). Interaksi Komunikasi Hoax di Media Sosial serta Antisipasinya. Jurnal Pekommas, 31-43.

Moleong, Lexy J. (2017). Metodologi Penelitian Kualitatif (Edisi Revisi). Bandung: PT Remaja Rosdakarya

Romli, Khomsah Rail. (2016). Komunikasi Massa. Jakarta : PT Grasindo.

Sari, W. P. (2015). Konflik Budaya Dalam Konstruksi Kecantikan Wanita Indonesia ( Analisis Semiotika Dan Marxist Iklan Pond's White Beauty Versi Gita Gutawa). Jurnal Komunikasi , 198-206.

Sobur, Alex. (2017). Semiotika Komunikasi, Bandung: PT Remaja Rosdakarya Offset. 